\title{
Phase 1 Methyl lodide Deep-Bed Adsorption Tests
}

Fuel Cycle Research \& Development

\author{
Prepared for \\ U.S. Department of Energy \\ System Analysis Campaign \\ by \\ Nick Soelberg \\ Tony Watson
}

August 22, 2014

FCRD- SWF-2014-000271

INL/EXT-14-32917 


\section{DISCLAIMER}

This information was prepared as an account of work sponsored by an agency of the U.S. Government. Neither the U.S. Government nor any agency thereof, nor any of their employees, makes any warranty, expressed or implied, or assumes any legal liability or responsibility for the accuracy, completeness, or usefulness, of any information, apparatus, product, or process disclosed, or represents that its use would not infringe privately owned rights. References herein to any specific commercial product, process, or service by trade name, trade mark, manufacturer, or otherwise, does not necessarily constitute or imply its endorsement, recommendation, or favoring by the U.S. Government or any agency thereof. The views and opinions of authors expressed herein do not necessarily state or reflect those of the U.S. Government or any agency thereof. 


\section{ACKNOWLEDGEMENTS}

We acknowledge others who helped guide or perform methyl iodide sorption testing this year. Jack Law of the Idaho National Laboratory (INL) and Bob Jubin of the Oak Ridge National Laboratory provided programmatic and technical direction. Cathy Rae in the INL Chemistry and Radiation Measurement Department provided considerable help with gas chromatography. Duane Ball and Byron White in the INL Chemistry and Radiation Measurement Department performed iodine sample analyses. 
This page blank 


\section{SUMMARY}

Nuclear fission produces fission products (FPs) and activation products, including iodine-129, which could evolve into used fuel reprocessing facility off-gas systems, and could require off-gas control to limit air emissions to levels within acceptable emission limits. Research, demonstrations, and some reprocessing plant experience have indicated that diatomic iodine can be captured with efficiencies high enough to meet regulatory requirements. Research on the capture of organic iodides has also been performed, but to a lesser extent. Several questions remain open regarding the capture of iodine bound in organic compounds.

Deep-bed methyl iodide adsorption testing has progressed according to a multi-laboratory methyl iodide adsorption test plan. This report summarizes the first phase of methyl iodide adsorption work performed according to this test plan using the deep-bed iodine adsorption test system at the Idaho National Laboratory (INL), performed during Fiscal Year (FY) 2013 and early FY-2014.

Testing has been performed to address questions posed in the test plan, and followed the testing outline in the test plan. Tests established detection limits, developed procedures for sample analysis with minimal analytical interferences, and confirmed earlier results that show that the methyl iodide reacts when in contact with the AgZ sorbent, and not significantly in the gas flow upstream of the sorbent. The reaction(s) enable separation of the iodine from the organic moiety, so that the iodine can chemisorb onto the sorbent. The organic moiety can form other compounds, some of which are organic compounds that are detected and can be tentatively identified using GC-FID and GCMS.

Test results also show that other gas constituents $\left(\mathrm{NO}_{\mathrm{x}}\right.$ and/or $\left.\mathrm{H}_{2} \mathrm{O}\right)$ can affect the methyl iodide reactions. With $\mathrm{NO}_{x}$ and $\mathrm{H}_{2} \mathrm{O}$ present in the gas stream, the majority of uncaptured iodine exiting iodineladen sorbent beds is in the form of $\mathrm{I}_{2}$ or $\mathrm{HI}$, species that are soluble in $\mathrm{NaOH}$ scrubbing solution used for iodine analysis. But when $\mathrm{NO}_{\mathrm{x}}$ and $\mathrm{H}_{2} \mathrm{O}$ are not present, then the majority of the uncaptured iodine exiting iodine-laden sorbent remains in the form of methyl iodide.

Methyl iodide adsorption efficiencies have been high enough so that initial DFs exceed 1,000. The methyl iodide mass transfer zone depths are estimated at 4-8 inches, possibly deeper than mass transfer zone depths estimated for $\mathrm{I}_{2}$ adsorption on $\mathrm{AgZ}$.

Additional deep-bed testing and analyses are recommended to (a) expand the data base for methyl iodide adsorption under various conditions specified in the methyl iodide test plan, and (b) provide more data for evaluating organic iodide reactions and reaction byproducts for different potential adsorption conditions. 
This page blank 


\section{TABLE OF CONTENTS}

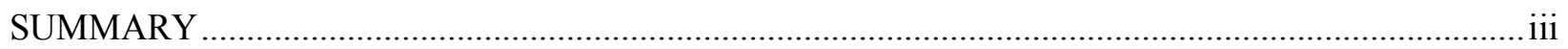

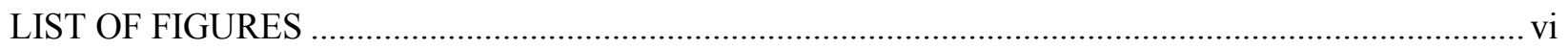

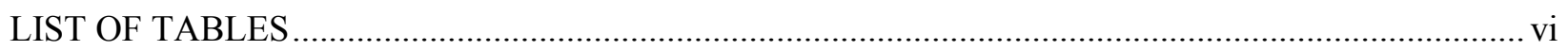

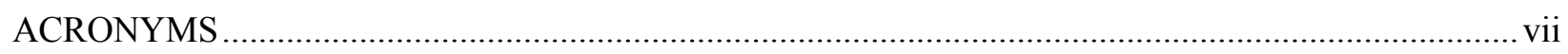

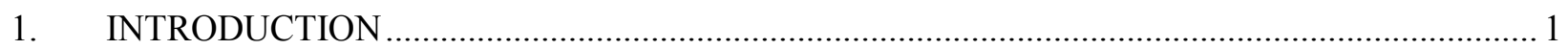

2. DEEP BED IODINE SORBENT TEST SYSTEM ................................................................ 1

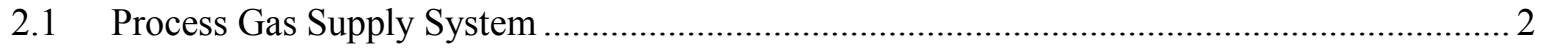

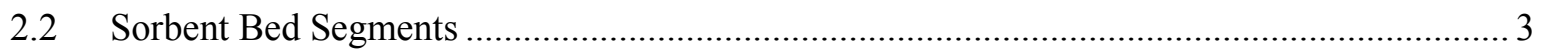

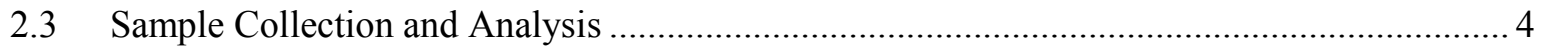

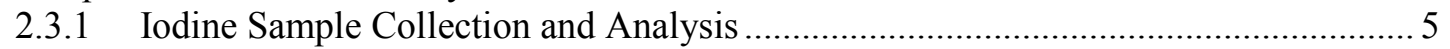

2.3.2 Organic Compound Sampling and Analysis ........................................................ 5

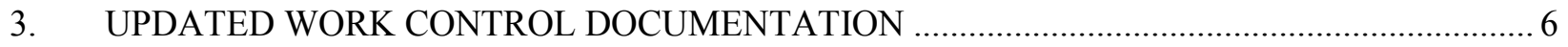

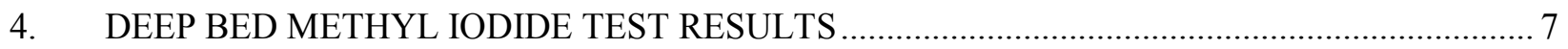

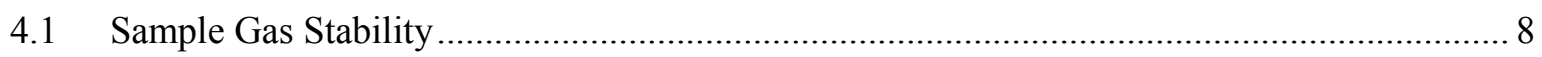

4.2 Methyl Iodide Adsorption Test Results ...................................................................... 9

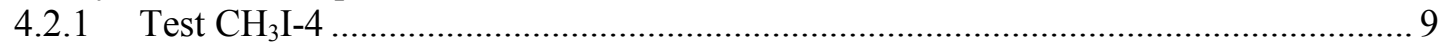

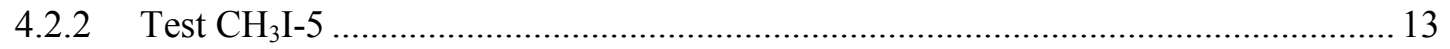

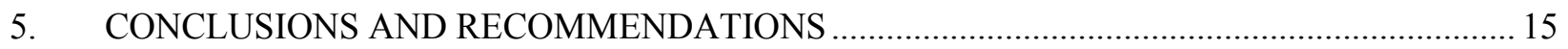

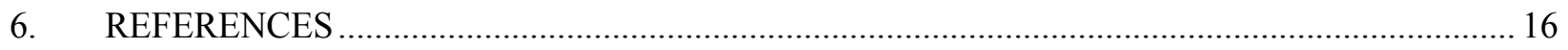




\section{LIST OF FIGURES}

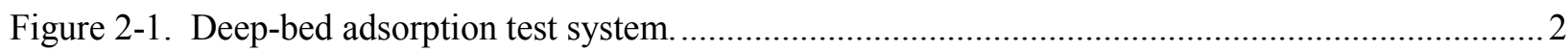

Figure 2-2. View of the iodine impingers and the permeation tube iodine or methyl iodide

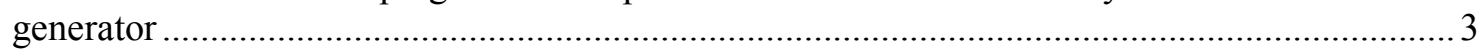

Figure 2-3. Detail of the sorbent beds. At times, only three of the four beds are used............................ 4

Figure 2-4. Configuration of the sorbent beds inside the temperature-controlled oven............................. 5

Figure 4-1. Stability of $\mathrm{CH}_{3} \mathrm{I}$ gas mixtures in foil-covered glass sample tubes. .................................... 9

Figure 4-2. AgZ sorbent in the sorbent beds prior to the test. ........................................................ 11

Figure 4-3. AgZ sorbent in the sorbent beds following the test...................................................... 11

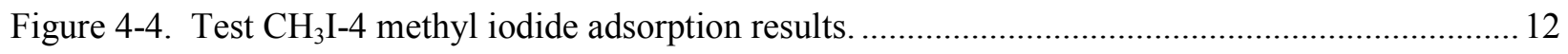

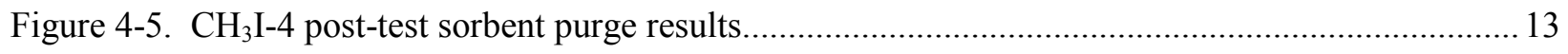

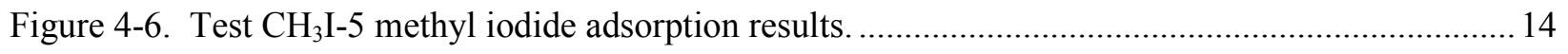

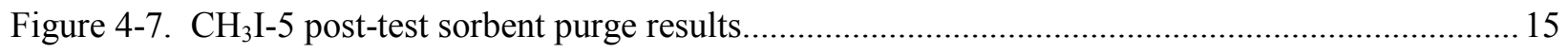

\section{LIST OF TABLES}

Table 4-1. Results of the Phase 1 methyl iodide tests performed through the first half of FY2014. 7

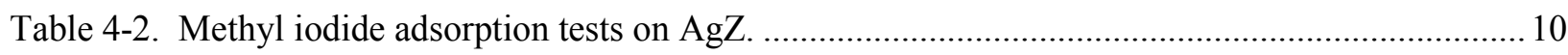




\section{ACRONYMS}

$\begin{array}{ll}\text { AgZ } & \text { silver zeolite } \\ \text { DF } & \text { decontamination factors } \\ \text { DL } & \text { detection limit } \\ \text { DOE } & \text { Department of Energy } \\ \text { ECD } & \text { electron capture detector } \\ \text { FCT } & \text { Fuel Cycle Technology } \\ \text { FID } & \text { flame ionization detector } \\ \text { FP } & \text { fission product } \\ \text { FY } & \text { fiscal year } \\ \text { GC } & \text { gas chromatograph } \\ \text { GCMS } & \text { gas chromatography with mass spectrometry } \\ \text { ICPMS } & \text { inductively coupled plasma mass spectrometry } \\ \text { INL } & \text { Idaho National Laboratory } \\ \text { ORNL } & \text { Oak Ridge National Laboratory } \\ \text { SPME } & \text { solid-phase micro-extraction }\end{array}$


This page blank 


\section{INTRODUCTION}

Nuclear fission results in the production of fission products (FPs) and activation products. If used nuclear fuel is reprocessed, some of those FPs and activation products, including iodine-129, could evolve into the process off-gas systems, and would likely require off-gas control to limit air emissions to levels within acceptable emission limits.

The Department of Energy (DOE) Fuel Cycle Technology (FCT) Program has supported research and development on iodine control and iodine waste forms for the past several years. The Offgas Sigma Team was formed in 2009 within the Separations and Waste Forms Campaign (now called the FCT Material Recovery \& Waste Form Development Campaign) to establish a team of researchers from different DOE sites to focus on research and development for emissions control and waste forms for volatile radionuclides.

Capture efficiencies for I-129 may need to be high enough to achieve off-gas decontamination factors (DFs) of at least 1,000x (99.9\% capture efficiency) to comply with applicable reprocessing facility regulatory requirements [Jubin 2012]. Iodine control may need to be used on multiple reprocessing facility off-gas streams (such as the head end off-gas, dissolver off-gas, vessel off-gas, and waste treatment off-gas streams), because I-129 in the used fuel is likely to distribute at up to percent levels to different off-gas streams [Jubin 2013]. Iodine is known to exist in off-gas streams as diatomic $\mathrm{I}_{2}$, and also react with organic species such as organic solvents or organic diluents used in actinide separations, or degradation products of those organic compounds, to form organic iodides.

Research, demonstrations, and some reprocessing plant experience have indicated that diatomic iodine can be captured with efficiencies high enough to meet regulatory requirements [Soelberg 2013]. Research on the capture of organic iodides has also been performed, but to a lesser extent [Jubin 2012b]. Several questions remain open regarding the capture of iodine bound in organic compounds.

A test plan identifies organic iodide data gaps and outlines a multi-year test program for advancing the state of understanding and capabilities for capturing organic iodides on solid sorbents [Jubin 2012b]. This report summarizes the first phase of methyl iodide adsorption work performed according to this test plan using the deep-bed iodine adsorption test system at the Idaho National Laboratory (INL), performed during Fiscal Year (FY) 2013 and early FY-2014.

All work was performed in compliance with work control documentation that was updated in FY2013 to ensure data quality, worker safety, environmental protection, and regulatory compliance during testing (INL 2013).

\section{DEEP BED IODINE SORBENT TEST SYSTEM}

Figure 2-1 shows a process diagram for the iodine test system. The main components are the:

- Process gas supply and blending system, which supplies gases from gas cylinders, iodine gas species generators, and a humidifier

- Multiple sorbent bed system inside a heated oven

- Process gas bypass

- Inlet and bed segment outlet gas sampling system. 


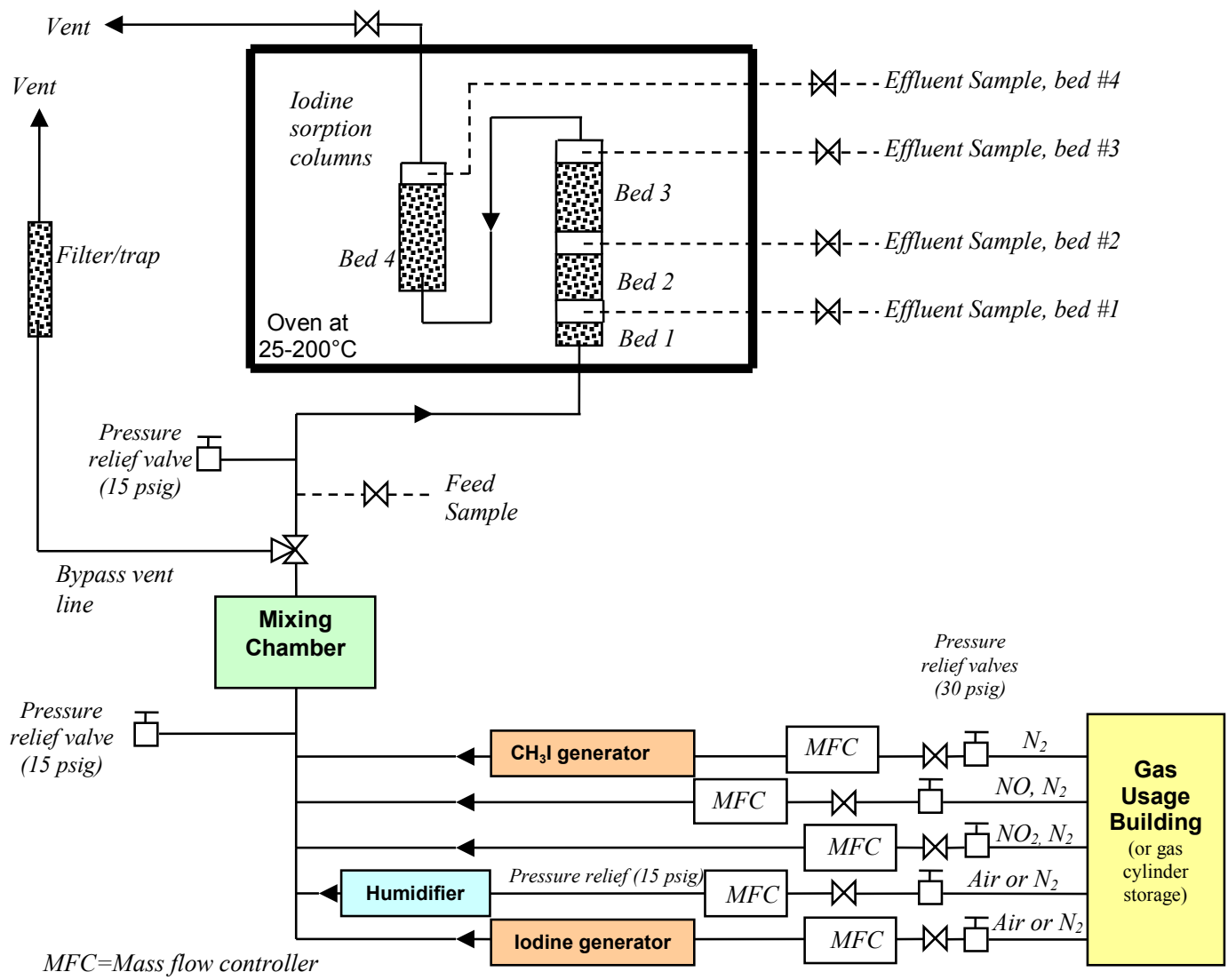

Figure 2-1. Deep-bed adsorption test system.

\subsection{Process Gas Supply System}

The process gas supply system consists of pressurized gas cylinders that supply the gases that are blended together to make the gas mixture that is passed through the sorbent beds. These gases can include (depending on the test) pure air, nitrogen, $\mathrm{NO}_{\mathrm{x}}$, water vapor, diatomic iodine, and methyl iodide (as a surrogate for organic iodide). Air or $\mathrm{N}_{2}$ can be supplied through mass flow controllers separately to the iodine and methyl iodide generators and the humidifier. $\mathrm{NO}$ and $\mathrm{NO}_{2}$ gases, with balance $\mathrm{N}_{2}$, are supplied from compressed gas cylinders through mass flow controllers.

Methyl iodide and iodine gases can be provided using compressed gas cylinders, permeation tubes, or a fixed bed iodine generator. The choice of methyl iodide and iodine source depends on the flowrate needed to achieve the target concentration in the test gas mixture. For lower methyl iodide concentrations under about $1 \mathrm{ppm}$, compressed gas cylinders or a permeation tube system may be used. For low iodine concentrations (under about $2 \mathrm{ppm}$ ) or for methyl iodide concentrations above about $1 \mathrm{ppm}$, the permeation tube system is used. For higher iodine concentrations above about $2 \mathrm{ppm}$, a fixed bed of iodine crystals interspersed in glass beads (which prevents iodine crystal agglomeration) is used.

The permeation tube system uses semi-permeable tubes that contain liquid methyl iodide (or solid iodine crystals) to emit a known flowrate of methyl iodide (or iodine) at a constant rate which is 
controlled by the operating temperature of the tube. The tubes (up to two), from VICI Metronics, are placed inside a Dynacalibrator Model 190 constant temperature permeation tube system (shown in Figure 2-2) also from VICI Metronics.

The gas flowrates and the generation rates of vaporized iodine, methyl iodide, and water are set to achieve the target gas composition and blended in a mixing chamber upstream of the sorbent beds. All process lines that contain vaporized iodine, methyl iodide, or water are electrically heat traced.

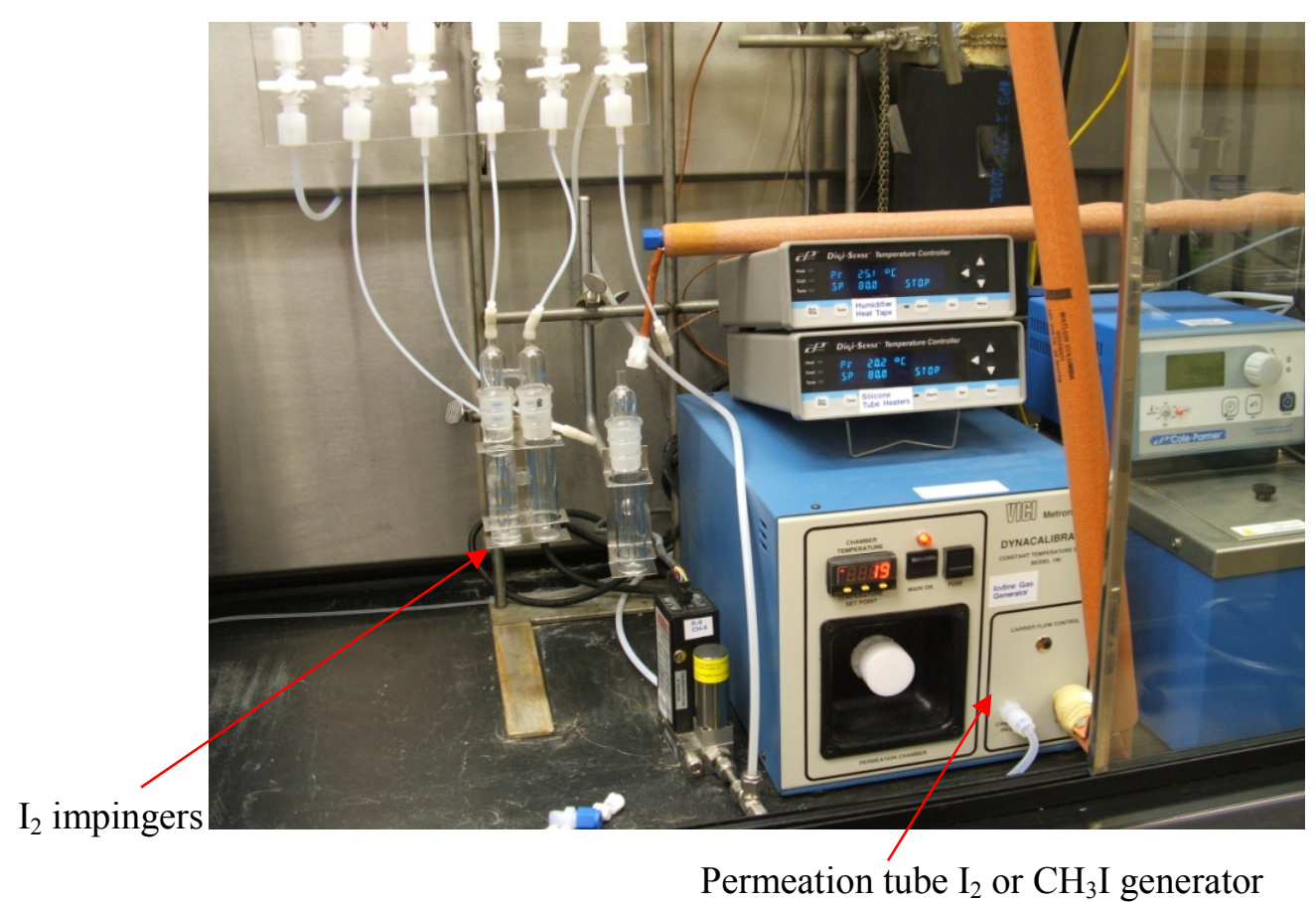

Figure 2-2. View of the iodine impingers and the permeation tube iodine or methyl iodide generator

Humidified air is produced by passing air or nitrogen through a fritted glass bubbler submerged in a constant temperature water bath. A thermocouple in the headspace of the bubbler provides the temperature of the water-saturated gas. The concentration of water in the blended gas is controlled by adjusting the gas flowrate through the humidifier and the humidifier operating temperature.

\subsection{Sorbent Bed Segments}

Figures 2-3 and 2-4 show detail of the sorbent beds and how the sorbent beds are configured in a temperature-controlled oven. The current test design includes up to four sorbent bed segments. The sorbent bed segments are made of borosilicate glass. A glass frit at the bottom of each bed segment supports the granular sorbent. 


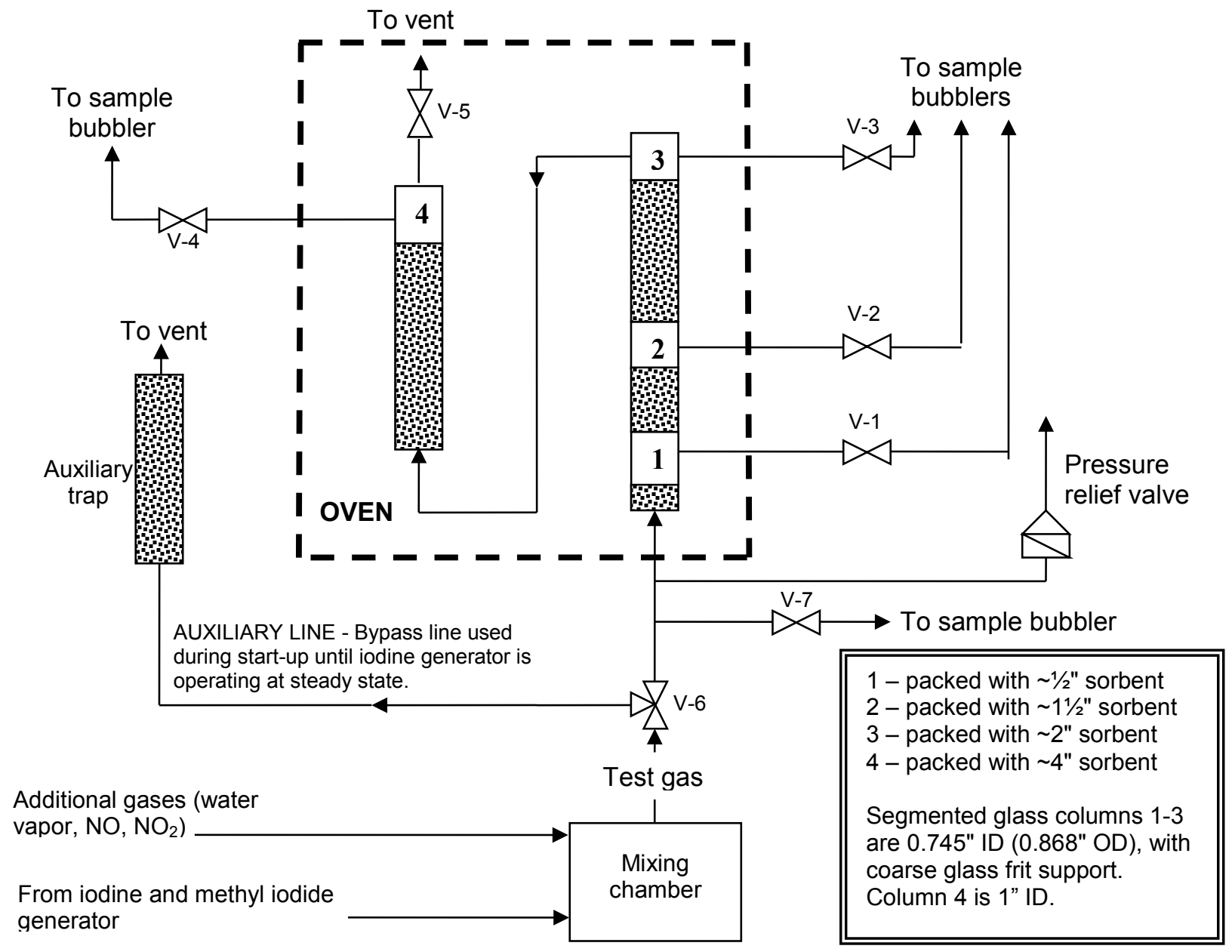

Figure 2-3. Detail of the sorbent beds. At times, only three of the four beds are used.

\subsection{Sample Collection and Analysis}

Iodine and methyl iodide concentrations in the test gas can be measured at up to five locations in the test system - at the inlet to the sorbent bed segments, and at the outlet of each of up to four bed segments. Since the gas flowrate is essentially the same at all five sample locations, the removal efficiencies for the sorbent in all four beds can be determined by measuring the iodine and methyl iodide concentrations at these locations. By integrating over time and using the test gas flowrate, the sorption efficiencies and the amounts of iodine and methyl iodide sorbed on each of the beds can be calculated.

The amount of sorbed iodine can also be determined gravimetrically by weighing the sorbent before and after each test. 


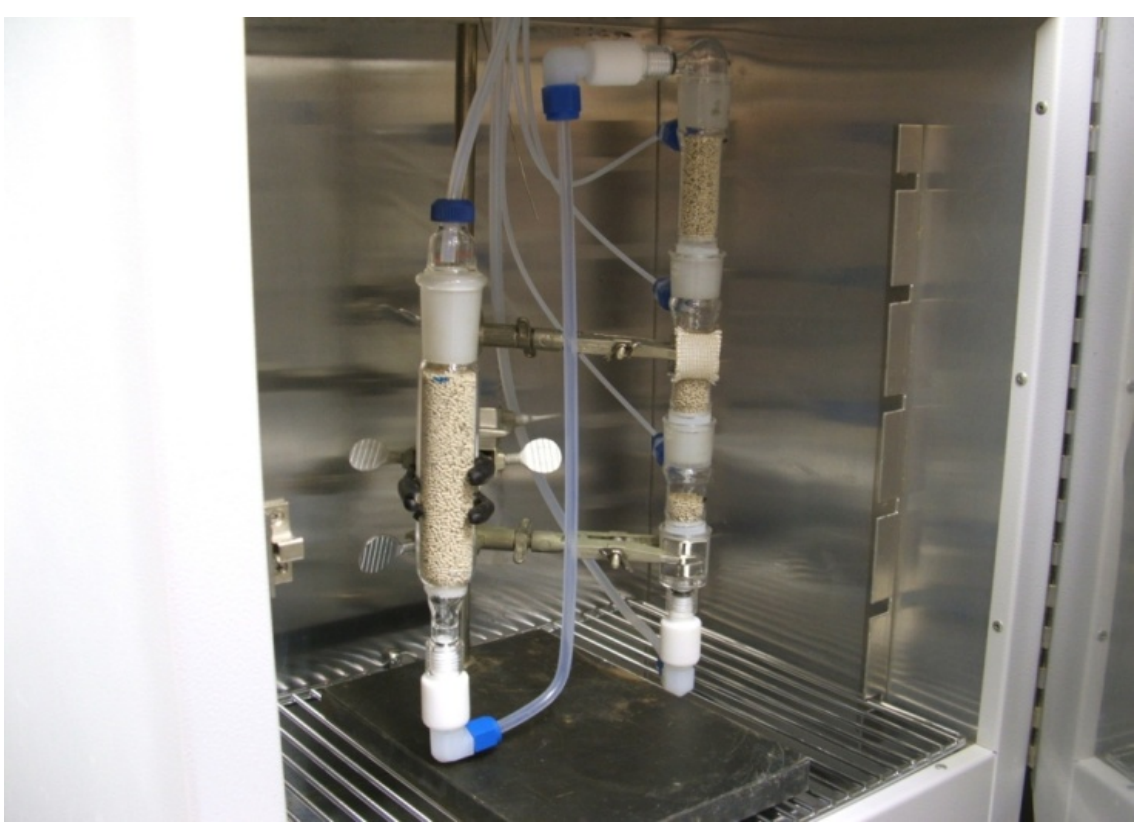

Figure 2-4. Configuration of the sorbent beds inside the temperature-controlled oven.

\subsection{1 lodine Sample Collection and Analysis}

Iodine measurements are made even when iodine is not included in the test gas mixture to determine if, or how much, iodine is being formed from reactions of methyl iodide.

For measuring the gaseous iodine concentration, the process gas from any of the five sample locations is passed through $25-\mathrm{ml}$ "midget" impingers that contain $0.1 \mathrm{~N} \mathrm{NaOH}$ for scrubbing halogen gases including $I_{2}$ and HI, if present. This technique is modeled after EPA Method 26 "Determination of Hydrogen Halide and Halogen Emissions from Stationary Sources, Non-Isokinetic Method" (40 CFR 60 Appendix A). The caustic solution dissolves halogens by hydrolyzing halogen gases to form a proton $\left(\mathrm{H}^{+}\right)$and hypohalous acid.

Any HI, if present, dissolves by dissociating in the caustic solution, and is included with $\mathrm{I}_{2}$ in the analysis. So this test method does not discriminate between $\mathrm{I}_{2}$ and $\mathrm{HI}$ or other iodine species that are soluble in $0.1 \mathrm{~N} \mathrm{NaOH}$. Testing was initially tried using an impinger of $0.1 \mathrm{~N}$ sulfuric acid upstream of the $\mathrm{NaOH}$ impingers, intended to quantitatively separate $\mathrm{HI}$ (which is soluble in $0.1 \mathrm{~N}$ sulfuric acid) from the $\mathrm{I}_{2}$. This concept is modeled after EPA Method 6, which uses the separate sulfuric acid and $\mathrm{NaOH}$ impingers to separate $\mathrm{HCl}, \mathrm{HF}$, and $\mathrm{HBr}$ from $\mathrm{Cl}_{2}, \mathrm{~F}_{2}$, and $\mathrm{Br}_{2}$. However, these initial test results showed that too much $\mathrm{I}_{2}$ was retained in the sulfuric acid impinger to provide a valid $\mathrm{HI}-\mathrm{I}_{2}$ separation.

The bubbler solutions are analyzed by inductively coupled plasma mass spectrometry (ICPMS) per EPA Method 6020A (SW-846, "Test Methods for Evaluating Solid Wastes Physical/Chemical Methods," http://www.epa.gov/osw/hazard/testmethods/sw846/online/). The gaseous iodine detection limit (DL) is about $0.08 \mathrm{ppb}$ with this method. Higher-concentration samples for gas streams with $1 \mathrm{ppm}$ or higher iodine concentrations are typically diluted for analysis.

\subsubsection{Organic Compound Sampling and Analysis}

Methyl iodide analysis using gas chromatography (GC) has evolved over time due to the corrosive nature of the typical test gas. Early testing used a Hewlett-Packard model 5890 Series II gas chromatograph (GC) installed in-line with the sample loop, thereby allowing near real-time analysis of methyl iodide [Haefner 2010]. An Rt-Q-BOND fused silica capillary column was used in the GC. The 
GC was equipped with an electron capture detector (ECD), which is very sensitive for measuring halogenated organic compounds. The minimum detection limit for this GC setup was about $5 \mathrm{ppb}$.

This early testing indicated that the use of the sample loop (which enables frequent and automatic sampling) and the highly sensitive ECD resulted in apparent corrosion of GC components resulting in erroneous measurements. The GC was frequently down for maintenance. Essentially all components that contacted the sample gas were eventually replaced, and the GC continued to frequently malfunction.

Beginning in FY-2013, the GC was replaced with another Hewlett Packard 5890 GC, equipped with a RTX-624, $30 \mathrm{~m}$ x $0.32 \mathrm{~mm}$ ID, $1.8 \mu \mathrm{m}$ df column, and a flame ionization detector (FID). The sample loop was not used. This caused the sampling and analysis to be more operator time-intensive, and reduced the number of GC measurements that are practical, but reduced the amount of time that the GC components are exposed to the corrosive sample gas.

The FID is not as sensitive for methyl iodide analysis as was the ECD. The methyl iodide detection limit was about $1 \mathrm{ppm}$ using direct injections. When lower detection limits are desired then a solid-phase micro-extraction (SPME) syringe is used. A SPME adsorbs organic compounds onto a solid-phase sorbent in a needle, thereby concentrating the amount of analyte. The adsorbed analytes are then desorbed into the GC carrier gas at an elevated temperature.

The SPME syringe is a Supelco brand, containing $75 \mu \mathrm{m}$ carboxen/polydimethylsiloxane fiber. The SPME and GC are calibrated together for specified adsorption and desorption times and temperatures. Using a SPME improves the methyl iodide detection limit by approximately $100 \mathrm{x}$ to approximately 10 ppb.

Unknown organic compounds formed by reactions of methyl iodide can appear as additional peaks on the GC-FID chromatograms. When this occurs, they can be tentatively identified using gas chromatography - mass spectroscopy (GCMS) analysis. The GCMS used for this work is a Shimadzu GC2010 with GCMS-QP2010 (with autosampler). The column is a J\&W Scientific DB-1 (dimethyl polysiloxane) column, $30 \mathrm{~m}$ x $0.25 \mathrm{~mm}$ ID x $1 \mu \mathrm{m}$ df.

\section{UPDATED WORK CONTROL DOCUMENTATION}

The deep-bed iodine testing work control documentation was reviewed and updated in FY-2013 in an INL-wide effort to ensure safety in experimental work performed at the INL, in response to an accident in another INL laboratory (unrelated to the deep-bed iodine adsorption testing program). The INL provides work controls through "Laboratory Instruction" documents which follow the Integrated Safety Management System to:

- Define the scope of work

- Analyze the hazards

- Develop and implement hazard controls

- Perform work within controls

- Provide feedback and continuous improvement

The Laboratory Instruction document for the deep-bed adsorption tests [INL 2013] was reviewed and updated over a 5-month period to ensure that this work was performed safely, especially considering the hazards related to the toxic gases and periods of overnight unattended operation during long-duration adsorption tests. During this time, no iodine adsorption testing was allowed until the LI was updated and approved. Project expenditures on this work control activity reduced the amount of experimental work accomplished during FY-2013. 


\section{DEEP BED METHYL IODIDE TEST RESULTS}

Methyl iodide testing proceeded according to the joint methyl iodide test plan [Jubin 2012b]. Results of Phase 1 testing through the first half of FY-2014 are reported in this document. (Results through the second half of FY-14 will be reported in a Level 3 milestone report due at the end of FY-2014.) Results through the first half of FY-2014 are summarized in Table 4-1, and discussed in more detail in the following sections.

Table 4-1. Results of the Phase 1 methyl iodide tests performed through the first half of FY-2014.

\begin{tabular}{|c|c|c|c|}
\hline $\begin{array}{l}\text { Question from } \\
\text { Jubin 2012b }\end{array}$ & Test conditions & & Results \\
\hline \multicolumn{3}{|c|}{$\begin{array}{l}\text { How stable are methyl iodide gas samples in sample } \\
\text { containers awaiting analysis? }\end{array}$} & Stable $(<\mathbf{2 0} \%$ loss) for up to 5 hours. \\
\hline $\begin{array}{l}\text { (1.b.i. in test } \\
\text { plan) }\end{array}$ & $\begin{array}{l}\text { Mixed gas samples } \\
\text { containing air, } \mathrm{CH}_{3} \mathrm{I} \text {, } \\
\text { and } \mathrm{NO}_{\mathrm{x}} \text {. }\end{array}$ & \multicolumn{2}{|c|}{$\begin{array}{l}\text { Gas samples in Tedlar and Mylar bags were found to have lingering contamination } \\
\text { when re-used, and tended to decrease in } \mathrm{CH}_{3} \mathrm{I} \text { concentration. } \\
\text { Gas samples in glass tubes experienced less contamination when re-used. Lower } \\
\mathrm{CH}_{3} \mathrm{I} \text { concentrations were stable with less than } \sim 20 \% \text { loss for over } 5 \text { hours. Higher } \\
\mathrm{CH}_{3} \mathrm{I} \text { concentrations were stable for up to } 3-5 \text { hours. After } 5-80 \mathrm{hrs}, \mathrm{CH}_{3} \mathrm{I} \text { levels } \\
\text { decreased by between } 29-82 \% \text {. } \\
\text { Based on these results, gas standards for GC calibrations and samples for GC and } \\
\text { GCMS analysis were analyzed within } 1-4 \text { hours after sample collection. }\end{array}$} \\
\hline \multicolumn{3}{|c|}{ Will $\mathrm{CH}_{3} \mathrm{I}$ react in test gas stream without sorbent? } & No, not in amounts greater than $1-3 \%$. \\
\hline $\begin{array}{l}\mathrm{CH}_{3} \mathrm{I}-1 \\
\text { (1.b.ii. in test } \\
\text { plan) }\end{array}$ & $\begin{array}{l}\text { Blank, no sorbent, } \\
4.3 \mathrm{~m} / \mathrm{s} \text { air velocity, } \\
150^{\circ} \mathrm{C} \text { temperature, } 2 \\
\text { ppm } \mathrm{H}_{2} \mathrm{O}\end{array}$ & \multicolumn{2}{|c|}{$\begin{array}{l}\text { Good blanks, no measureable contamination, good detection limits. } \\
\mathrm{CH}_{3} \mathrm{I} \text { DL } \sim 0.01 \mathrm{ppmv} \text { (GC-FID with SPME); } \sim 1 \mathrm{ppm} \text { with GC-FID direct injection. } \\
\mathrm{I}_{2} \mathrm{DL} \sim 0.001 \mathrm{ppmv} \text { (NaOH bubbler, ICPMS). }\end{array}$} \\
\hline $\begin{array}{l}\mathrm{CH}_{3} \mathrm{I}-2 \\
\text { (1.b.ii. in test } \\
\text { plan) }\end{array}$ & $\begin{array}{l}19 \mathrm{ppm} \mathrm{CH}_{3} \mathrm{I}, \text { no } \\
\text { sorbent, } 4.3 \mathrm{~m} / \mathrm{s} \text { air } \\
\text { velocity, } 150^{\circ} \mathrm{C} \\
\text { temperature, } 2 \mathrm{ppm}\end{array}$ & \multicolumn{2}{|c|}{$\begin{array}{l}\text { Small if any gas-phase reaction. Measured } 0.29 \mathrm{ppm} \mathrm{I}_{2}, 1.5 \% \text { of the input } \mathrm{CH}_{3} \mathrm{I} \\
\text { concentration. }\end{array}$} \\
\hline $\begin{array}{l}\mathrm{CH}_{3} \mathrm{I}-3 \\
\text { (1.b.ii. Test } 1 \text { in } \\
\text { test plan) }\end{array}$ & $\begin{array}{l}33 \mathrm{ppm} \mathrm{CH}_{3} \mathrm{I}, \text { no } \\
\text { sorbent, } 4.3 \mathrm{~m} / \mathrm{s} \text { air } \\
\text { velocity, } 824 \mathrm{ppmv} \\
\mathrm{NO}, 824 \mathrm{ppm} \mathrm{NO} \mathrm{NO}_{2} \text {, } \\
1.8 \% \mathrm{H}_{2} \mathrm{O}\left(\sim 16^{\circ} \mathrm{C}\right. \\
\text { DP) }\end{array}$ & \multicolumn{2}{|c|}{$\begin{array}{l}\text { Higher but still small potential gas-phase reaction. Measured } 1.3 \mathrm{ppm} \mathrm{I}_{2}(3.4 \% \text { of } \\
\text { total iodine). }\end{array}$} \\
\hline
\end{tabular}


Table 4-1. Results of the Phase 1 methyl iodide tests performed through the first half of FY-2014 (continued).

\begin{tabular}{|c|c|c|c|c|}
\hline $\begin{array}{l}\text { Question from } \\
\text { Jubin } 2012 b\end{array}$ & Test conditions & \multicolumn{3}{|c|}{ Results } \\
\hline \multicolumn{4}{|c|}{ Can the results of INL 2010 deep bed test results be confirmed (Haefner 2010 ) - is $I_{2} / \mathrm{HI}$ formed? } & Yes. \\
\hline $\begin{array}{l}\mathrm{CH}_{3} \mathrm{I}-4 \\
\text { (1.b.ii.1. Test } 1 \\
\text { in test plan) }\end{array}$ & $\begin{array}{l}57 \mathrm{ppm} \text { average } \\
\mathrm{CH}_{3} \mathrm{I}, \mathrm{AgZ} \text { sorbent, } \\
4.3 \mathrm{~m} / \mathrm{s} \text { air velocity, } \\
824 \mathrm{ppmv} \mathrm{NO}, 824 \\
\text { ppm } \mathrm{NO}_{2}, 1.8 \% \mathrm{H}_{2} \mathrm{O} \\
\left(\sim 16^{\circ} \mathrm{C} \mathrm{DP}\right)\end{array}$ & \multicolumn{3}{|c|}{$\begin{array}{l}\text { Initial } \mathrm{CH}_{3} \mathrm{I} \mathrm{DF} \sim 6,800 \text {. } \\
\text { Outlet } \mathrm{CH}_{3} \mathrm{I} \text { levels increased from nondetectable }(0.01 \mathrm{ppm}) \text { to } 41 \mathrm{ppm}(\sim 55 \% \text { of } \\
\text { input } \mathrm{CH}_{3} \mathrm{I} \text { at the test end) as the Bed } 1 \text { sorbent became more iodine-laden, after } \\
\text { breakthrough. } \\
\text { Outlet } \mathrm{I}_{2} / \mathrm{HI} \text { levels increased from } 0.001 \mathrm{ppm} \text { to as high as } \sim 10 \mathrm{ppm} \text { at the outlet of } \\
\text { Bed } 3(\sim 13 \% \text { of input iodine after breakthrough. } \\
\text { Of the total Bed } 4 \text { outlet unabsorbed iodine at test end, about } 2 \% \text { remained } \mathrm{CH}_{3} \mathrm{I} \text {; } \\
\text { about } 98 \% \text { was in the form of } \mathrm{I}_{2} / \mathrm{HI} \text {, confirming that after iodine breakthrough } \\
\text { occurred, most of the uncaptured iodine was in the form of } \mathrm{I}_{2} / \mathrm{HI} \text {, consistent with the } \\
2010 \text { test results for similar test conditions. } \\
\text { Could not identify additional peaks suspected to be compounds containing } \mathrm{CH}_{3} \\
\text { moiety separated from the adsorbed iodine. }\end{array}$} \\
\hline \multicolumn{3}{|c|}{ Same test conditions as Test $\mathrm{CH}_{3} \mathrm{I}-4$ except no $\mathrm{NO}_{x}$ or $\mathrm{H}_{2} \mathrm{O}-$ is $\mathrm{I}_{2} / \mathrm{HI}$ formed? } & \multicolumn{2}{|c|}{ Yes, but to a much smaller extent. } \\
\hline $\begin{array}{l}\mathrm{CH}_{3} \mathrm{I}-5 \\
\text { (1.b.ii.1. Test } 2 \\
\text { in test plan) }\end{array}$ & $\begin{array}{l}31 \mathrm{ppm} \text { average } \\
\mathrm{CH}_{3} \mathrm{I}, \mathrm{AgZ} \text { sorbent, } \\
4.3 \mathrm{~m} / \mathrm{s} \text { air velocity, } \\
\text { no } \mathrm{NO}_{\mathrm{x}} \text {, no added } \\
\mathrm{H}_{2} \mathrm{O}, 2 \mathrm{ppm} \mathrm{H}_{2} \mathrm{O}\end{array}$ & $\begin{array}{l}\text { Initial } \mathrm{CH}_{3} \mathrm{I} \mathrm{DF} \sim 34,000 \text {. } \\
\text { Outlet } \mathrm{CH}_{3} \mathrm{I} \text { levels increased from no } \\
\left.\text { input } \mathrm{CH}_{3} \mathrm{I}\right) \text { after breakthrough. } \\
\text { Outlet } \mathrm{I}_{2} / \mathrm{HI} \text { levels increased from } 0.0 \\
\text { breakthrough. } \\
\text { Of the total Bed } 4 \text { outlet unabsorbed } \\
\mathrm{CH}_{3} \mathrm{I} \text {; about } 5 \% \text { was in the form of } \mathrm{I}_{2} \\
\text { With no } \mathrm{NO}_{\mathrm{x}} \text { and very low } \mathrm{H}_{2} \mathrm{O} \text { in th } \\
\text { unabsorbed iodine was converted to I } \\
\text { unabsorbed iodine remained in the fo } \\
\mathrm{CH}_{3} \mathrm{I}-4 \text { test, in which nearly all of the } \\
\text { the form of } \mathrm{I}_{2} / \mathrm{HI} \text {. } \\
\text { Methanol }\left(\mathrm{CH}_{3} \mathrm{OH}\right) \text { and dimethyl eth } \\
\text { although not at levels high enough to } \\
\text { separated from the adsorbed iodine. }\end{array}$ & $\begin{array}{l}\text { ectable }(0.01 \mathrm{ppn} \\
\text { opm to } 0.5 \mathrm{ppm}(3 \\
\text { he after breakthro } \\
\text { stream, only a s } \\
\text { after breakthrou } \\
{\mathrm{f} \mathrm{CH}_{3} \mathrm{I} \text {. This res }}_{\text {bsorbed iodine a }} \\
\left.\mathrm{CH}_{2} \mathrm{OCH}_{3}\right) \text { have b } \\
\text { ntitatively accoun }\end{array}$ & $\begin{array}{l}0 \text { ppm ( } 92 \% \text { of } \\
\text { input iodine) after } \\
\text { bout } 95 \% \text { remained } \\
\text { ortion of the } \\
\text { early all of the } \\
\text { different from the } \\
\text { eakthrough was in } \\
\text { he } \mathrm{CH}_{3} \text { moiety }\end{array}$ \\
\hline
\end{tabular}

\subsection{Sample Gas Stability}

Tests of sample containers were performed to determine the best sample containers to use and how long $\mathrm{CH}_{3} \mathrm{I}$ levels can be stable, with less than about 20\% loss, after sample collection. Tedlar and Mylar bags indicated lingering contamination combined with $\mathrm{CH}_{3} \mathrm{I}$ loss within a few hours. Foil-covered glass sample tubes proved to have little contamination and adequate retention of $\mathrm{CH}_{3} \mathrm{I}$ over time, as shown in Figure 4-1. Glass sample tubes with foil covering were determined to be the best sample container. Gas standards for GC calibrations and samples for GC and GCMS analysis were analyzed within 1-4 hours after sample collection.

Based on these results, glass tubes were used for sample collection for GC and GCMS analysis. 


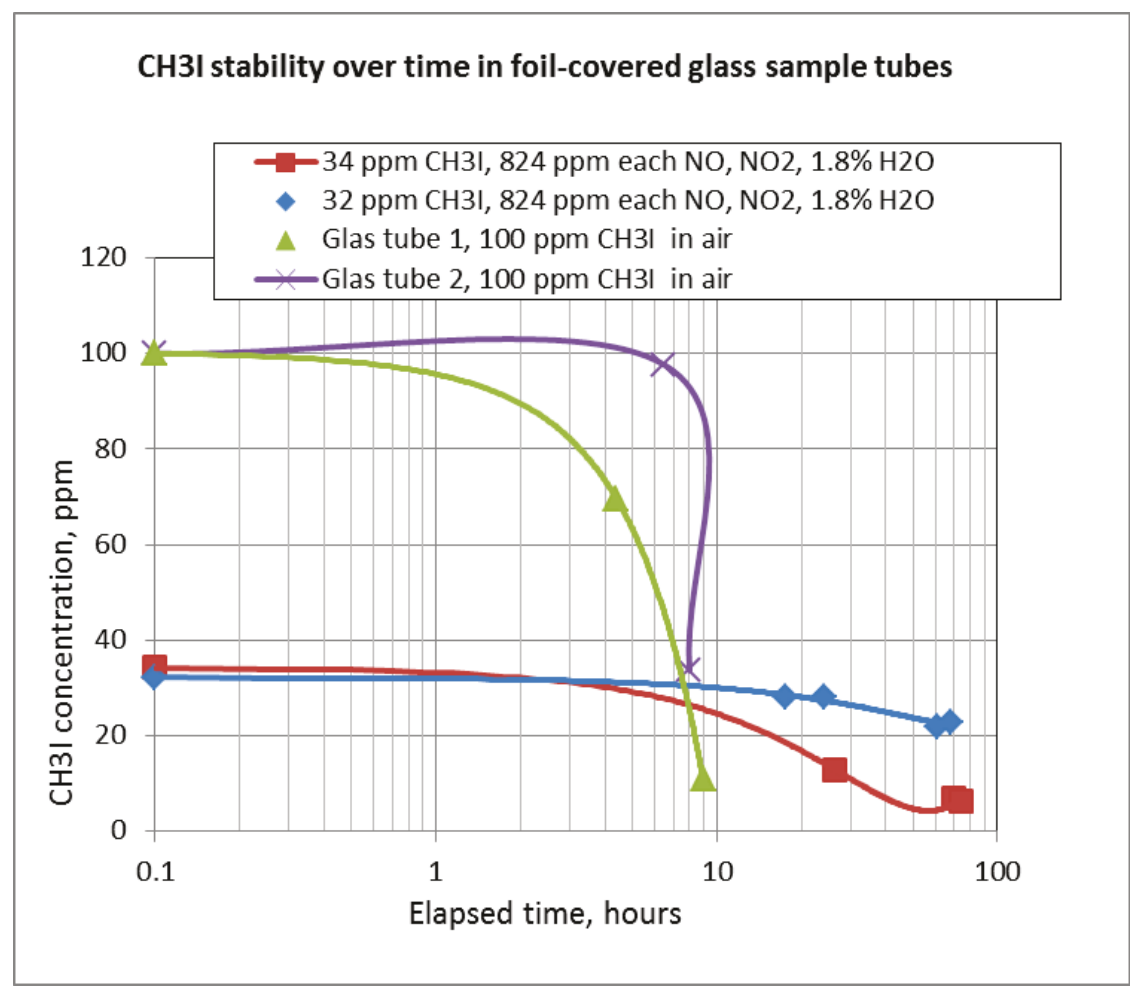

Figure 4-1. Stability of $\mathrm{CH}_{3} \mathrm{I}$ gas mixtures in foil-covered glass sample tubes.

\subsection{Methyl lodide Adsorption Test Results}

Two long-duration methyl iodide adsorption tests are reported here. Table 4-2 summarizes the results for these two tests.

\subsubsection{Test $\mathrm{CH}_{3} \mathrm{I}-4$}

This test was designed to repeat the deep-bed methyl iodide test reported in Haefner 2010, which indicated that, after sorbent breakthrough, significant amounts of unadsorbed iodine can be in the form of $\mathrm{I}_{2}$ or HI, and not the original methyl iodide that entered the sorbent bed.

This test was performed with the same approximate gas composition, which included methyl iodide, $\mathrm{NO}, \mathrm{NO}_{2}$, and $\mathrm{H}_{2} \mathrm{O}$. Silver zeolite (AgZ) was the sorbent, with a presumed silver content of $9.5 \mathrm{wt} \%$. This sorbent was chemically reduced to convert the silver to $\mathrm{Ag}^{\circ}$ and provided by Oak Ridge National Laboratory (ORNL).

Figure 4-2 shows the AgZ sorbent in the sorbent beds prior to the test. Figure 4-3 shows the AgZ sorbent following the test. The pre-test sorbent granules are colored varying shades of grey and brown. The post-test sorbent, especially in Beds 1and2, turned a lighter beige color. 
Table 4-2. Methyl iodide adsorption tests on AgZ.

\begin{tabular}{|c|c|c|}
\hline Run Number & $\begin{array}{c}\mathrm{CH} 3 \mathrm{I} 433 \mathrm{ppm} \\
\mathrm{CH} 3 \mathrm{I} \text { w/ NOx, } \mathrm{H} 2 \mathrm{O}\end{array}$ & $\begin{array}{c}\mathrm{CH} 3 \mathrm{I} 533 \mathrm{ppm} \\
\mathrm{CH} 3 \mathrm{I} \text { w/o } \\
\mathrm{NO} \times \mathrm{H} 2 \mathrm{O}\end{array}$ \\
\hline Simulate what off-gas? & Dissolver & Dissolver \\
\hline Test start date & 17-Jun-13 & 23-Sep-13 \\
\hline \multicolumn{3}{|l|}{ Sorption conditions } \\
\hline Temperature, deg. C & 150 & 150 \\
\hline Total gas flowrate, sccm & 728 & 730 \\
\hline Target $\mathrm{CH} 3 \mathrm{I}$ conc, ppmv & 52 & 44 \\
\hline Measured $\mathrm{CH} 3 \mathrm{I}$ conc, ppmv & 57.1 & 30.8 \\
\hline Target I2 conc, ppmv & 0.0 & 0.0 \\
\hline Measured 12 conc, ppmv & 0.96 & 0.20 \\
\hline Measured total I flowrate, $\mathrm{mg} / \mathrm{min}$ & -- & --- \\
\hline $\mathrm{H} 2 \mathrm{O}$ conc, $\%$ & 1.8 & 0.0 \\
\hline NO conc., ppmv & 824 & 0 \\
\hline NO2 conc., ppmv & 824 & 0 \\
\hline Balance & air & air \\
\hline Gas flowrate, standard I/min & 0.73 & 0.73 \\
\hline Sorption gas velocity, $\mathrm{m} / \mathrm{min}$ & 4.3 & 4.3 \\
\hline Bed 1 out residence $t, \mathrm{sec}$ & 0.18 & 0.18 \\
\hline Bed 2 out cumulative residence $t$, sec & 0.71 & 0.70 \\
\hline Bed 3 out cumulative residence $t$, sec & 1.41 & 1.41 \\
\hline Bed 4 out cumulative residence $t, \mathrm{sec}$ & 3.92 & 3.91 \\
\hline$\%$ I conversion to 12 & $3.4 \%$ & $1.3 \%$ \\
\hline Cumulative test duration, $\mathrm{hr}$ & 466 & 424 \\
\hline Max iodine loadings from grav analysis & $5.8 \%$ & $5.0 \%$ \\
\hline Max silver utilization, \% & $61 \%$ & $53 \%$ \\
\hline Max DF before breakthrough & 6,768 & 33,858 \\
\hline Max conversion of bed outlet $\mathrm{CH} 3 \mathrm{I}$ to $\mathrm{I} 2$ & $98 \%$ & $5 \%$ \\
\hline Mass transfer zone depth, inches & 4-8 inches & 4-8 inches \\
\hline \multirow[t]{2}{*}{ Organic compounds detected } & \multirow[t]{2}{*}{$\begin{array}{l}\text { Unable to } \\
\text { determine }\end{array}$} & $\begin{array}{c}\text { dimethyl ether, } \\
\mathrm{C} 2 \mathrm{H} 6 \mathrm{O}\end{array}$ \\
\hline & & methanol, $\mathrm{CH} 3 \mathrm{OH}$ \\
\hline
\end{tabular}




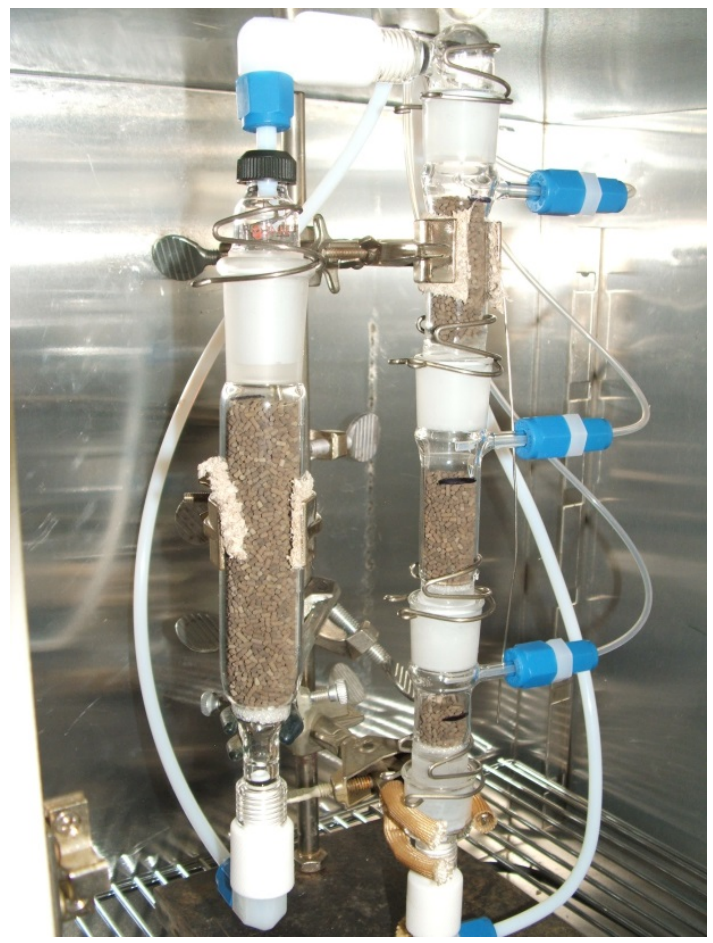

Figure 4-2. AgZ sorbent in the sorbent beds prior to the test.

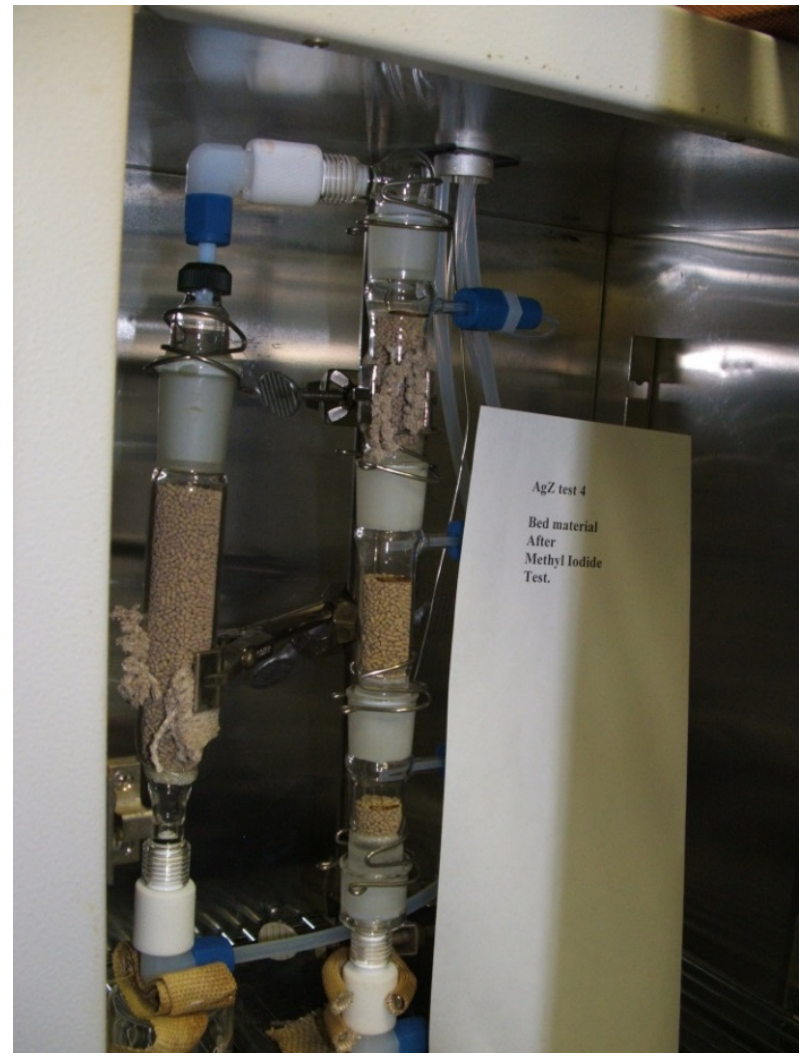

Figure 4-3. AgZ sorbent in the sorbent beds following the test. 
Figure 4-4 shows results of this test. At the test start, the highest measured DF (at the outlet of Bed 3, 4 inches deep in the bed) was about 7,000. The DF at the outlet of Bed 4 was not measured until later in the test. The initial DF at the outlet of Bed 1, 0.5 inches deep in the bed, was about 600 . The DFs at the Bed 1,2, and 3, outlets rapidly decreased until by hour 75, the Bed 1 DF was near 1 (almost saturated), the Bed 2 DF was about 80, and the Bed 3 DF was about 100. The rapid decrease in the DFs for the bed depth up to 4 inches show that the depth of the mass transfer zone was at least 4 inches.

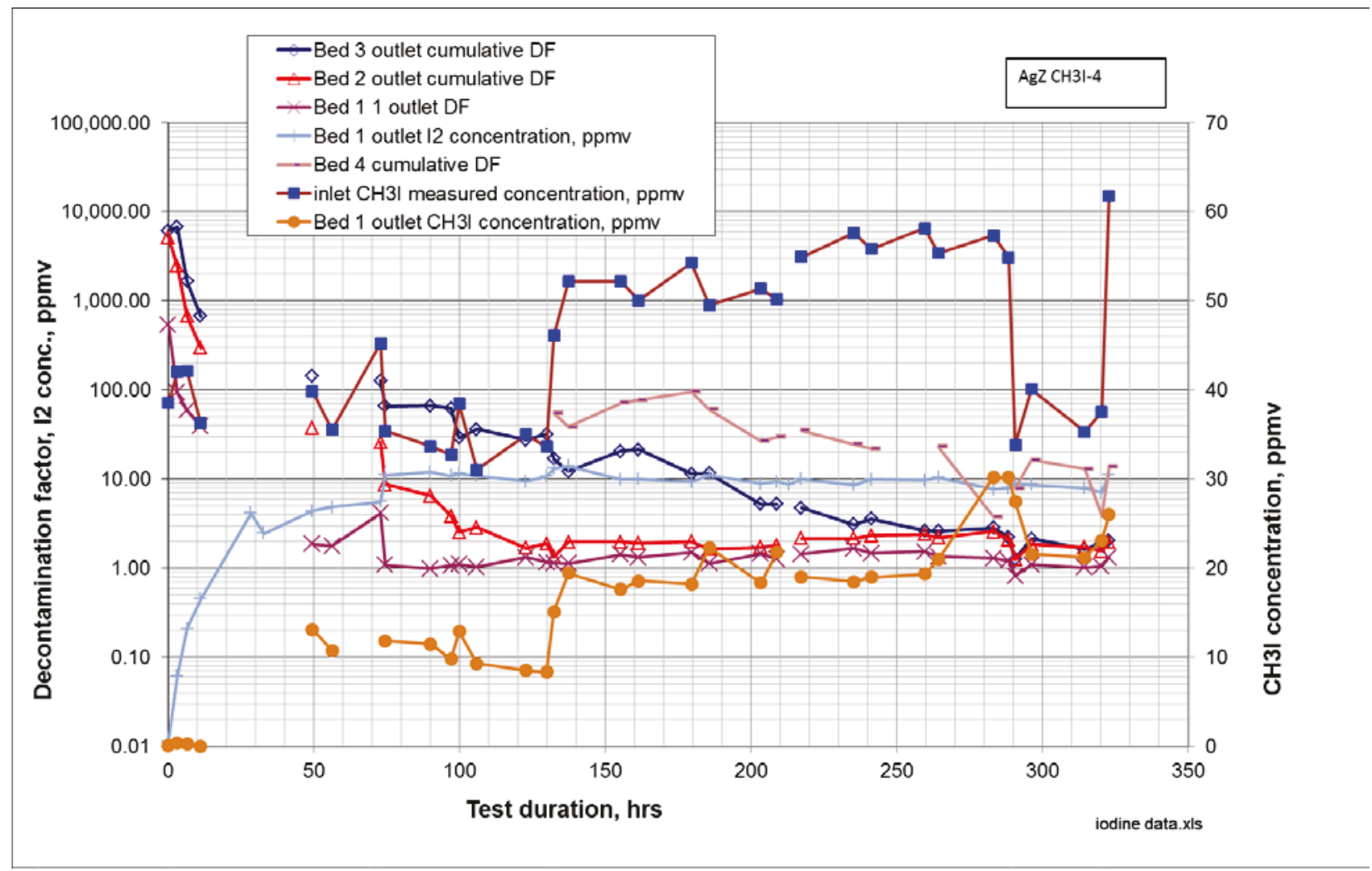

Figure 4-4. Test $\mathrm{CH}_{3} \mathrm{I}-4$ methyl iodide adsorption results.

The DF for Bed 1 remained near 1 for the rest of the test, indicating that it was nearly saturated after about hour 75. By hour 120, the Bed 2 outlet DF decreased to about 2, and remained at about 2 for the rest of the test. The Bed 3 outlet DF steadily decreased until it reached about 2 at about hour 240 . Bed 4 DF (at total of 8 inches bed depth) measurements that started at about hour 130 decreased from about 50100 to about 4-20 by hour 270, as the leading edge of the mass transfer zone progressed into the 4-8 inch deep Bed 3. This indicates that the initial mass transfer zone was less than 8 inches.

As each bed became progressively laden with iodine, outlet gaseous $\mathrm{CH}_{3} \mathrm{I}$ levels increased from near zero to 20-30 ppm at the outlet of Bed 1, when the inlet $\mathrm{CH}_{3} \mathrm{I}$ levels ranged between 35-60 ppm. Simultaneously, levels of $\mathrm{I}_{2} / \mathrm{HI}$ increased from near zero to about $10 \mathrm{ppm}$. The combined gaseous $\mathrm{CH}_{3} \mathrm{I}$ and $\mathrm{I}_{2} / \mathrm{HI}$ levels in the Bed 1 outlet gas nearly match the iodine in the input $\mathrm{CH}_{3} \mathrm{I}$.

As the process gas flowed through the four bed segments, the methyl iodide continued to be adsorbed or reacted. At the 8-inch-deep Bed 4 outlet, the $\mathrm{I}_{2} / \mathrm{HI}$ level increased to about $8 \mathrm{ppm}$ at the test end, and the $\mathrm{CH}_{3} \mathrm{I}$ concentration was only about $0.7 \mathrm{ppm}$. The gaseous $\mathrm{I}_{2} / \mathrm{HI}$ represented about $96 \%$ of the 
uncaptured iodine, and the gaseous $\mathrm{CH}_{3} \mathrm{I}$ represented about $4 \%$ of the uncaptured iodine. This very closely matches the results of the 2010 deep-bed test, when the $\mathrm{I}_{2} / \mathrm{HI}$ represented $97 \%$ of the uncaptured iodine.

After each test, the sorbent beds were purged to desorb any amounts of iodine that may be loosely or physisorbed. The purge results for this test are shown in Figure 4-5. This figure shows that only a small fraction of the iodine sorbed on Bed 1 was desorbed during the 24-hr purge period. During the purge period, the Bed 1 outlet $\mathrm{I}_{2} / \mathrm{HI}$ and $\mathrm{CH}_{3} \mathrm{I}$ levels decreased to 2 to 4 orders of magnitude lower than Bed 1 outlet $\mathrm{I}_{2} / \mathrm{HI}$ and $\mathrm{CH}_{3} \mathrm{I}$ levels that occurred near the end of the sorption test. The cumulative amount of total iodine that was desorbed from Bed 1 increased from about $0.3 \%$ at the start of the purge period to about $4 \%$.

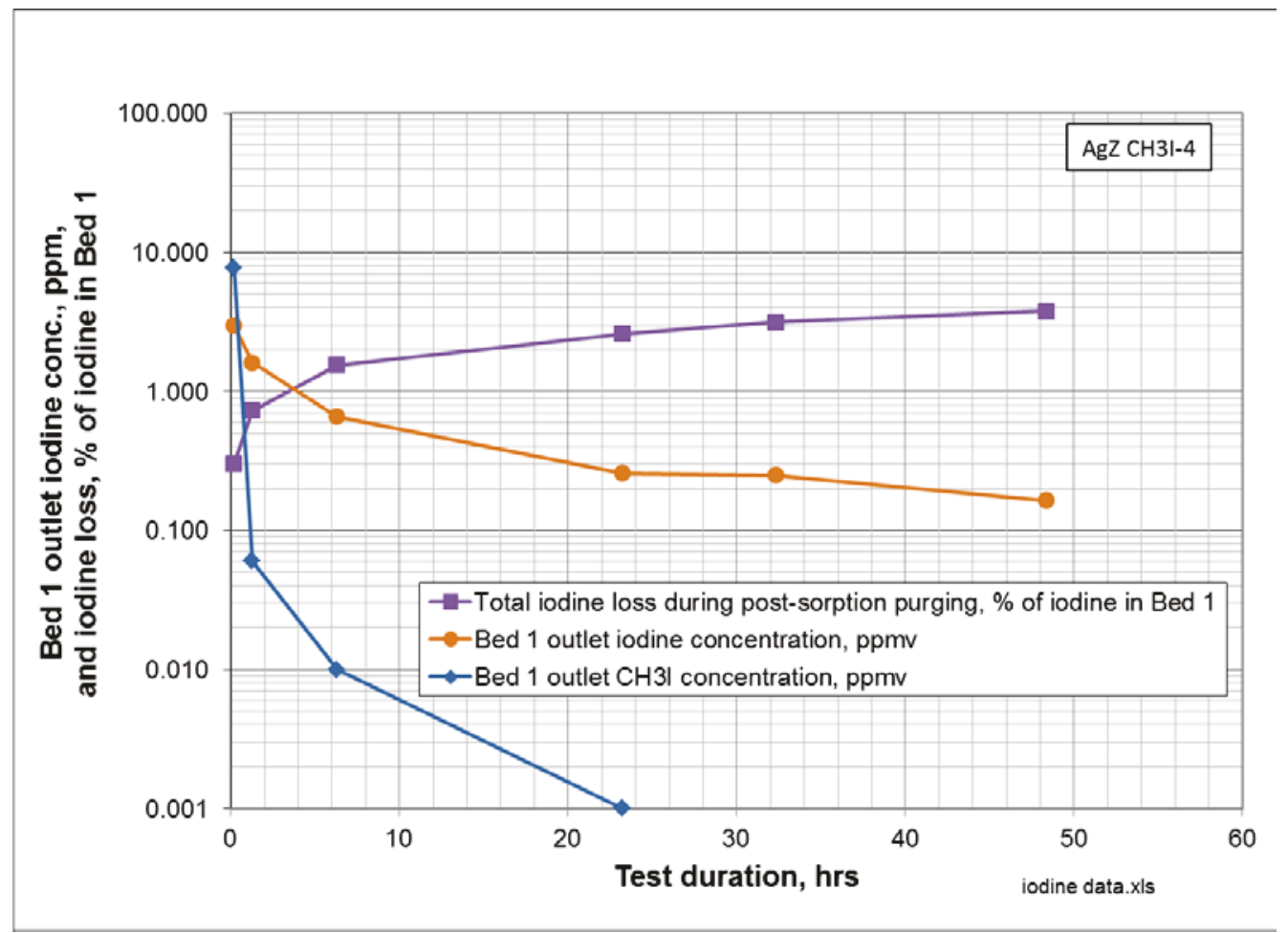

Figure 4-5. $\mathrm{CH}_{3} \mathrm{I}-4$ post-test sorbent purge results.

The same trends occurred at the outlet of Beds 2, 3, and 4. Levels of $\mathrm{CH}_{3} \mathrm{I}$ decreased within the purge period to their detection limits. Levels of $\mathrm{I}_{2} / \mathrm{HI}$ decreased by about one order of magnitude during the purge period.

\subsubsection{Test $\mathrm{CH}_{3} \mathrm{I}-5$}

This test was next in the test plan sequence [Jubin 2012b]. This test had the same test conditions as Test $\mathrm{CH}_{3} \mathrm{I}-4$, except with no added $\mathrm{NO}_{x}$ or $\mathrm{H}_{2} \mathrm{O}$. Silver zeolite $(\mathrm{AgZ})$ was the sorbent, with a presumed silver content of $9.5 \mathrm{wt} \%$. This sorbent was chemically reduced to convert the silver to $\mathrm{Ag}^{\mathrm{o}}$ and provided by ORNL.

Figure 4-6 shows results of this test. At or near the test start, the highest measured DF (at the outlet of Bed 4, 8 inches deep in the bed) was over 30,000, but the highest DFs for Beds 1, 2, and 3 (0.5 inches, 2 inches, and 4 inches deep) were already under 1,000. The rapid decrease in the DFs for the bed depth up to 4 inches show that the depth of the mass transfer zone was at least 4 inches. 


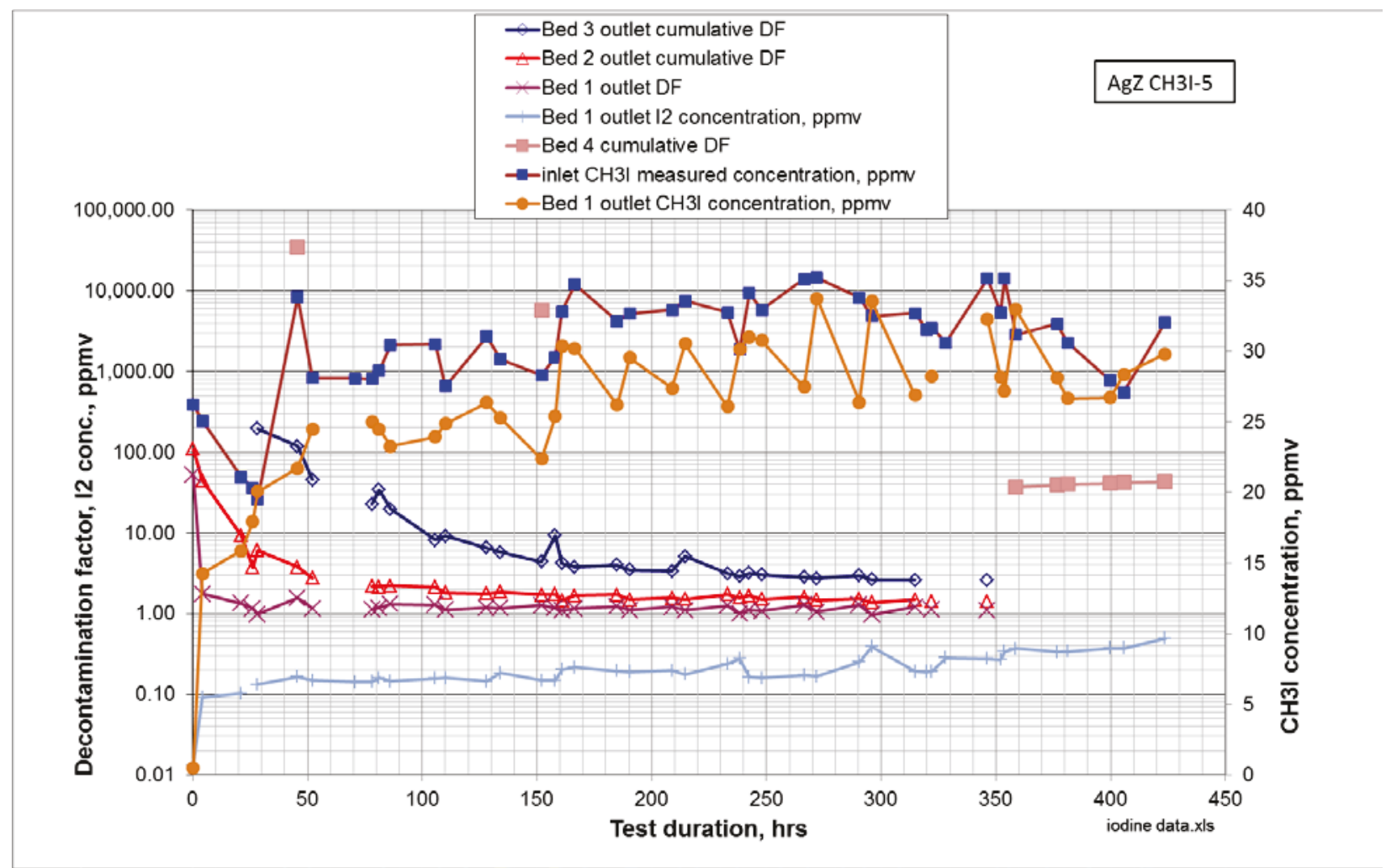

Figure 4-6. Test $\mathrm{CH}_{3} \mathrm{I}-5$ methyl iodide adsorption results.

The DF for Bed 1 decreased to near 1 by about hour 30, and remained near 1 for the rest of the test, indicating that it was nearly saturated. By hour 120, the Bed 2 outlet DF decreased to about 2. The Bed 2 outlet DF further decreased gradually to near 1 by the end of the test. The Bed 3 outlet DF steadily decreased until it nearly reached about 2 at about hour 350. Bed 4 DFs were only occasionally measured due to time limitations during sampling and analysis, but remained at about 6,000 after hour 150, and was still about 40 at the test end. This indicates that the depth of the mass transfer zone was less than 8 inches.

As each bed became progressively laden with iodine, outlet gaseous $\mathrm{CH}_{3} \mathrm{I}$ levels increased from near zero to 27-32 ppm at the outlet of Bed 1, when the inlet $\mathrm{CH}_{3} \mathrm{I}$ levels ranged mainly between 28-35 ppm. Simultaneously, levels of $\mathrm{I}_{2} / \mathrm{HI}$ increased from near zero to about $0.6 \mathrm{ppm}$. The combined gaseous $\mathrm{CH}_{3} \mathrm{I}$ and $\mathrm{I}_{2} / \mathrm{HI}$ levels in the Bed 1 outlet gas nearly match the iodine in the input $\mathrm{CH}_{3} \mathrm{I}$.

As the process gas flowed through the four bed segments, the methyl iodide continued to be adsorbed or reacted. At the 8-inch-deep Bed 4 outlet, the $\mathrm{I}_{2} / \mathrm{HI}$ level ranged as high as $0.02 \mathrm{ppm}$, and the $\mathrm{CH}_{3} \mathrm{I}$ concentration never exceeded $0.7 \mathrm{ppm}$. The gaseous $\mathrm{I}_{2} / \mathrm{HI}$ represented a maximum of about $6 \%$ of the uncaptured iodine, and the gaseous $\mathrm{CH}_{3} \mathrm{I}$ represented at least $94 \%$ of the uncaptured iodine. This ratio is very different from the results of the CH3I-4 test and the 2010 deep-bed test, when the $\mathrm{I}_{2} / \mathrm{HI}$ represented 96-97\% of the uncaptured iodine. This difference may have been due to lack of $\mathrm{NO}_{\mathrm{x}}$ and $\mathrm{H}_{2} \mathrm{O}$ in the process gas, either of which may have contributed to the $\mathrm{CH}_{3} \mathrm{I}$ reactions that resulted in the formation of gaseous, uncaptured $\mathrm{I}_{2} / \mathrm{HI}$.

The GC chromatograms showed several peaks in addition to the $\mathrm{CH}_{3} \mathrm{I}$ peak. Samples of gas from the bed outlets were periodically analyzed by GCMS in attempts to tentatively identify these organic 
compounds. The GCMS was not as sensitive for these organic compounds as was the GC-FID, so some peaks detected on the GC-FID chromatograms were not detected by the GCMS. Two compounds that were detected and tentatively identified were methanol and dimethyl ether. Additional evaluation and analysis of methyl iodide reactions and iodine adsorption on AgZ are reported in Nenoff 2014.

The post-test sorbent purge results for this test are shown in Figure 4-7. This figure shows that only a small fraction of the iodine sorbed on Bed 1 was desorbed during the 37-hr purge period. During the purge period, the Bed 1 outlet $\mathrm{I}_{2} / \mathrm{HI}$ and $\mathrm{CH}_{3} \mathrm{I}$ levels decreased to 1-3 orders of magnitude lower than Bed 1 outlet $\mathrm{I}_{2} / \mathrm{HI}$ and $\mathrm{CH}_{3} \mathrm{I}$ levels that occurred near the end of the sorption test. The cumulative amount of total iodine that was desorbed from Bed 1 increased from about $0.1 \%$ at the start of the purge period to about $0.5 \%$ at the end of the purge period.

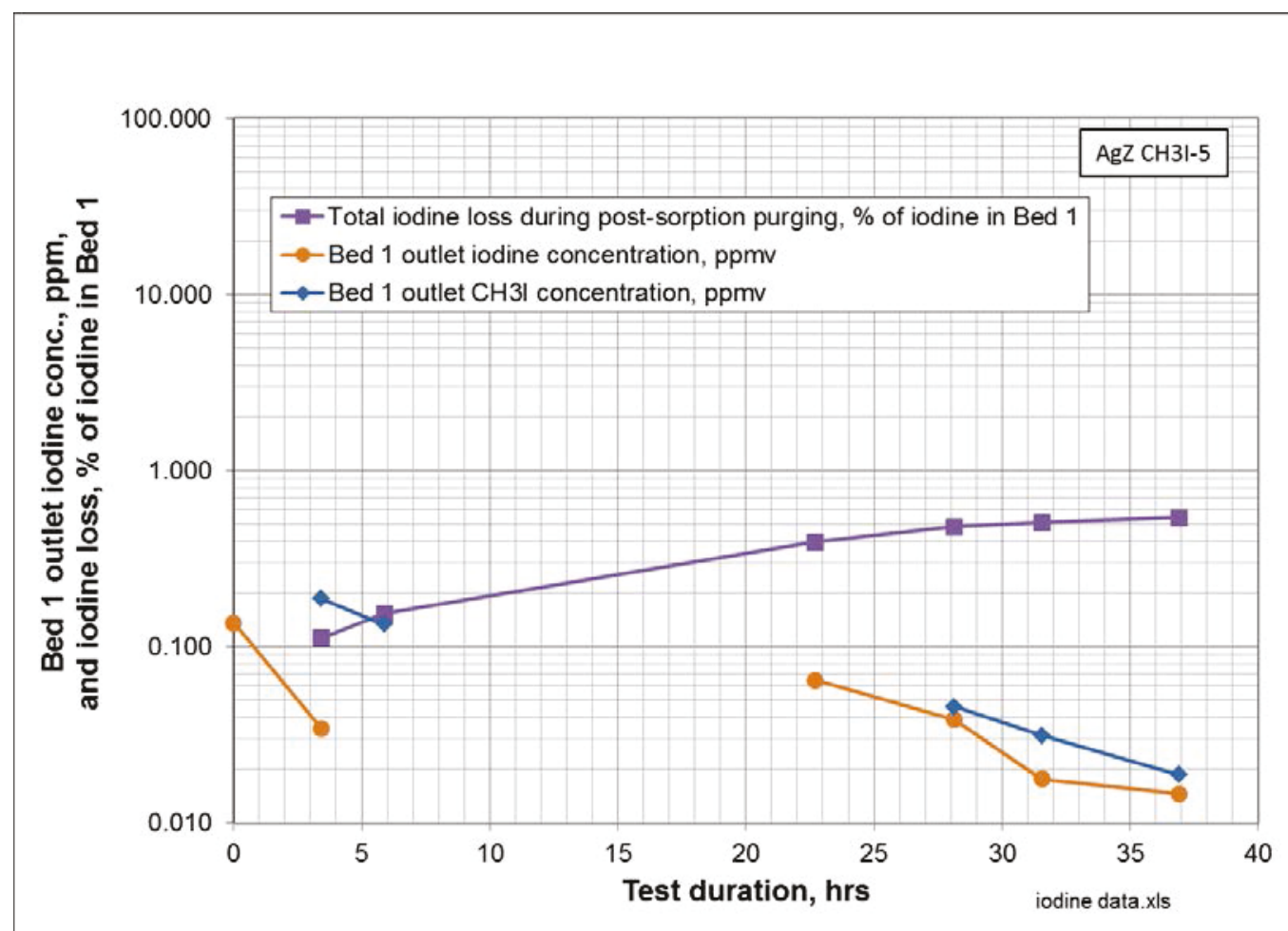

Figure 4-7. $\mathrm{CH}_{3} \mathrm{I}-5$ post-test sorbent purge results.

The same trends occurred at the outlet of Beds 2, 3, and 4. Levels of $\mathrm{CH}_{3} \mathrm{I}$ decreased within the purge period to their detection limits. Levels of $\mathrm{I}_{2} / \mathrm{HI}$ decreased by about one order of magnitude during the purge period.

\section{CONCLUSIONS AND RECOMMENDATIONS}

Deep-bed methyl iodide adsorption testing has progressed according to the multi-laboratory methyl iodide adsorption test plan [Jubin 2012b]. Testing has confirmed earlier results that show that the methyl iodide reacts when in contact with the AgZ sorbent, and not significantly in the gas flow upstream of the sorbent. The reaction(s) enable separation of the iodine from the organic moiety, so that the iodine can chemisorb onto the sorbent. The organic moiety can form other compounds, some of which are organic compounds that are detected and can be tentatively identified using GC-FID and GCMS. 
Test results also show that other gas constituents $\left(\mathrm{NO}_{\mathrm{x}}\right.$ and/or $\left.\mathrm{H}_{2} \mathrm{O}\right)$ can affect the methyl iodide reactions. With $\mathrm{NO}_{\mathrm{x}}$ and $\mathrm{H}_{2} \mathrm{O}$ present in the gas stream, the majority of uncaptured iodine exiting iodineladen sorbent beds is in the form of $\mathrm{I}_{2}$ or $\mathrm{HI}$, species that are soluble in $\mathrm{NaOH}$ scrubbing solution for iodine analysis. But when $\mathrm{NO}_{\mathrm{x}}$ and $\mathrm{H}_{2} \mathrm{O}$ are not present, the majority of the uncaptured iodine exiting iodine-laden sorbent is in the form of methyl iodide.

Methyl iodide adsorption efficiencies have been high enough so that initial DFs exceed 1,000. The methyl iodide mass transfer zone depths are estimated at 4-8 inches, possibly deeper than mass transfer zone depths estimated for $\mathrm{I}_{2}$ adsorption on $\mathrm{AgZ}$.

Additional deep-bed testing and analyses are recommended to (a) expand the data base for methyl iodide adsorption under various conditions specified in the methyl iodide test plan, and (b) provide more data for evaluating organic iodide reactions and reaction byproducts for different potential adsorption conditions.

\section{REFERENCES}

Haefner 2010

INL 2013

Jubin $2012 \mathrm{a}$

Jubin 2012b

Jubin 2013

Nenoff 2014

Soelberg 2013
Haefner, D. R., and T. Watson, "Summary of FY 2010 Iodine Capture Studies at the INL," INL/EXT-10-19657, August 2010.

“Gas Phase Iodine Capture Methods for Non-Radioactive Materials," Idaho National Laboratory, LI-1287-07-CFA, June 10, 2013.

R. T. Jubin, N. R. Soelberg, D. M. Strachan, and G. Ilas, 2012a, "Fuel Age Impacts on Gaseous Fission Product Capture during Separations," FCRD-SWF-2012-000089, Oak Ridge National Laboratory, 2012.

Jubin, R.T., B. B. Spencer, N. R. Soelberg, D. M. Strachan, T. M. Nenoff, 2012b, "Joint Test Plan to Identify the Gaseous By-Products of $\mathrm{CH}_{3} \mathrm{I}$ Loading on $\mathrm{AgZ}$," INL/EXT-12-27978, FCRD-SWF-2013-000070, December 26, 2012.

Jubin, R.T., D.M. Strachan, and N.R. Soelberg, "Iodine Pathways and Off-Gas Stream Characteristics for Aqueous Reprocessing Plants - A Literature Survey and Assessment," FCRD-SWF-2013-000308, ORNL/LTR-2013/383, INL/EXT-1330119, September 15, 2013.

Nenoff, Tina, Mark Rodriguez, Nick Soelberg, Karen Chapman, 2014, "SilverMordenite for Radiologic Gas Capture from Complex Streams: Dual Catalytic CH3I Decomposition and I Confinement," Microporous and Mesoporous Materials, MICMAT6530, INL/JOU-14-31276, 9 May 2014.

Soelberg, Nick R., Troy G. Garn, Mitchell R. Greenhalgh, Jack D. Law, Robert Jubin, Denis M. Strachan, and Praveen K. Thallapally, 2013, "Radioactive Iodine and Krypton Control for Nuclear Fuel Reprocessing Facilities," Hindawi Publishing Corporation, Science and Technology of Nuclear Installations, Volume 2013, Article ID 702496, 12 pages, http://dx.doi.org/10.1155/2013/702496. 